\title{
THE TERMITE RESISTANCE OF PINOSYLVIN, STILBENE AND OTHER NEW INSECTICIDES ${ }^{1}$
}

\section{GEORGE N. WOICOTT²}

The natural resistance to termite attack of some woods has long been known, but chemical analyses, to determine the specific chemical constituents responsible, have rarely been made. Until very recently almost the only exception seems to have been in the case of East Indian teak, Tectona grandis L. The well-known resistance to weathering, decay and insect attack of teakwood is apparently due to the presence of beta-methylanthraquinone (tectoquinone). A ten minute submersion in a $1 \%$ solution in acetone of tectoquinone will indefinitely protect susceptible woods against attack by the West Indian dry-wood termite, Cryptotermes brevis Walker, (Wolcott 1946). The partly-eaten keys of a piano (of which one key had already been replaced with a duplicate made of mahogany), heavily infested with these termites, have thus been successfully protected against further injury, despite the fact that the untreated remainder of the piano is falling to pieces, so rapidly is its oak case being devoured.

In the East Indies, tectoquinone is extracted from teakwood waste, and in the United States is synthesized by Eastman, but in neither case is cost of production sufficiently low that this chemical can be recommended for extensive commercial adoption. Tests of many other quinones and related compounds have indicated none that is even as effective in protection against termite attack as is this natural constituent of teakwood (Wolcott 1947).

Pinosylvin (3,5-hydroxystilbene) has been extracted from the heartwood of Scotch pine by Dr. Holger Erdtman, in charge of the Division of Organic Chemistry, the Royal Institute of Technology, Stockholm, Sweden. It has a diphenolic structure which "suggests that pinosylvin might be the main cause of the well-known great durability of pine heartwood" (Erdtman 1949). The sample very graciously submitted for test consisted of light, silvery flakes, of a delightful piney odor for some people, odorless to others, which floated on the surface of water, but dissolved instantly in alcohol or acetone like the first snowflakes of winter in a forest pool, and this solution could be diluted indefinitely with water without precipitation of the crystals. Using a standardized technique, fresh samples of flamboyán, Delonix regia (Bojer) Raf., were submerged for ten minutes in solutions of pinosylvin at $2 \%, 1 \%, 0.5 \%, 0.2 \%, 0.1 \%, 0.05 \%, 0.02 \%$ and $0.01 \%$ on July 6 th, 1950 . The next day, the sample impregnated with $0.01 \%$ pinosylvin was placed

\footnotetext{
${ }^{1}$ Presented at the Sixty-Second Annual Meeting of the American Association of Economic Entomologists, December 18-21, 1950, Denver, Colorado.

2 Entomologist, Head of Department.
} 
with fresh termites in a petri dish with similar samples of flamboyán treated with other chemicals. On the following morning half of the termites were dead or immobilized. For nearly two months, no termites have been able to live longer than two or three days in the petri dish containing this sample, but eventually it lost its toxicity. Five months after impregnation, a slight gouge was eaten in it, but in succeeding months, no fresh termites have enlarged this inconclusive initial attack.

Some inorganic chemicals, notably red mercuric iodide (Wolcott 1943), are initially very toxic to termites, but wood impregnated with them rapidly ceases to be either toxic or repellent. Many of the organic chemicals are also initially toxic, most notably zinc and copper dimethyldithiocarbamate, but none at such a great dilution or for so long a time as this one-hundredth of one per cent of pinosylvin.

Pinosylvin is not now commercially available, but stilbene (or transstilbene, Eastman No. 1817) $\mathrm{C}_{6} \mathrm{H}_{5} \mathrm{CH}: \mathrm{CHC}_{6} \mathrm{H}_{5}$, can be readily obtained. Its odor is not that of pine wood, but to the entomologist is reminiscent of a cotton field of which the leaves are being mass devoured by Alabama caterpillars. It is not so instantaneously soluble as is pinosylvin, but can be dissolved in benzol or acetone, making a colorless solution for the impregnation of wood. The treated samples of flamboyán wood, even at $2 \%$, are odorless, and unchanged in appearance. The $0.01 \%$ sample was toxic to termites for several weeks following impregnation, and although eaten by termites less than three months later, all these termites died. Fresh termites have not enlarged this feeding-gouge, and indeed all have died rather than eat the wood with $0.01 \%$ stilbene.

It should not be supposed that all the extractives of pine are similarly toxic or repellent to termites. Chrysin (5,7-dihydroxyflavone) and pinocembrin (5,7-dihydroxyflavonone), extracted by Dr. Gösta Lindstedt from sugar pine, although at first repellent, in less than three months are eaten: the $1 \%$ of chrysin and the $0.1 \%$ of pinocembrin. At the same time, the greatest dilutions of taxifolin $\left(3,5,7,3^{\prime}, 4^{\prime}\right.$-pentahydroxy-flavonone), from Douglas fir, and pinosylvin monomethyl ether (3-hydroxy-5-methoxystilbene) and dihydroxypinosylvin monomethyl ether (3-hydroxy-5-methoxydibenzyl) from Scotch pine, have not been attacked in five months after receipt for test.

The permanence of the protection afforded against termite attack is really of more fundamental importance in judging of the value of a chemical than its initial toxicity. Thus, although stilbene and the pinosylvin extractives from Scotch pine may indeed eventually prove to be all that their early promise indicates, the nearly seven years of proved resistance of $0.2 \%$ copper pentachlorphenate, and $2 \%$ pentachlorphenol and $2 \%$ DDT can not be lightly dismissed when compared with the value of chemicals more recently made available. Tests are being conducted at Río Piedras, and it 
is hoped that they will continue to be conducted, until some of the more promising of the newer chemicals have had ample time to prove their value.

As compared with DDT for instance, the butyl DDT at $2 \%$ impregnation was attacked in 120 days, and the fluorine DDT in 161 days, but at $0.05 \%$, the methyl DDT (duPont's Methoxychlor or Marlate) is still uneaten a year after treatment: a far better record than any of the other benzolsoluble compounds previously reported.

Dimethyl-tetrachlor-phthalate, from the Whitemarsh Laboratories, at this concentration has been uneaten a year and a half, as is also the sample treated with the plant extractive Ryanodine, from Ryania speciosa wood from Venezuela. The Laurel Hill Laboratories have submitted samples of somewhat similar compounds, one of which at $0.05 \%$ has not been attacked in a year and a half, while others of the series, with but slightly differing composition, are definitely inferior. Such differences in the reactions of termites (and other insects), are possibly to be expected after observing those shown to the gamma isomer of benzene hexachloride (Wolcott 1950), as compared with the lack of protective power possessed by its other isomers.

The constituents of Commercial Solvents' Dilan, and Naugatuck's Aramite show up equally well in preliminary tests. Somewhat disappointing are the records of the Hyman products, so promising at first, but ceasing to protect at $0.2 \%$ of impregnation after two years.

TABLE 1

Days after Submersion Ten Minutes in Solution before Attack by the West Indian Dry-Wood Termite, Cryptotermes brevis Walker

\begin{tabular}{|c|c|c|c|c|c|c|c|c|}
\hline Dilutions of & $0.01 \%$ & $0.02 \%$ & $|0.05 \%|$ & $0.1 \%$ & $0.2 \%$ & $0.5 \%$ & $1 \%$ & $2 \%$ \\
\hline Pinosylvin & \multirow{5}{*}{\multicolumn{8}{|c|}{$\begin{array}{l}\text { toxic for two months, inconclusively eaten in } \\
\text { five months } \\
\text { toxic three weeks, inconclusively eaten in } \\
\text { three months } \\
\text { uneaten in three months } \\
\text { uneaten in three months } \\
\text { uneaten in three months }\end{array}$}} \\
\hline Stilbene & & & & & & & & \\
\hline Taxifolin & & & & & & & & \\
\hline Pinosylvin monomethyl ether & & & & & & & & \\
\hline $\begin{array}{l}\text { Dihydropinosylvin monomethyl } \\
\text { ether }\end{array}$ & & & & & & & & \\
\hline $\begin{array}{l}\text { Pinocembrin (5,7-dihydroxy- } \\
\text { flavonone) }\end{array}$ & 57 & 72 & 74 & 78 & 102 & 107 & \multicolumn{2}{|c|}{$\begin{array}{l}\text { uneaten in } 5 \\
\text { months }\end{array}$} \\
\hline Chrysin (5,7-dihydroxyflavone) & 55 & 56 & 58 & 61 & 79 & 82 & \multicolumn{2}{|c|}{90 End } \\
\hline Tectoquinone (Eastman) & 3 & 6 & 24 & 36 & 46 & 596 & \multirow{2}{*}{\multicolumn{2}{|c|}{$\begin{array}{c}\text { uneaten } 6 \\
\text { years } \\
\text { ten in } 5 \text { vears }\end{array}$}} \\
\hline a-naphthaflavone & \multirow{2}{*}{\multicolumn{8}{|c|}{$\begin{array}{l}\text { toxic two months, eaten after } 204 \text { days } \\
\text { slightly eaten in three years }\end{array}$}} \\
\hline Ryanodine (Merck) & & & & & & & & \\
\hline
\end{tabular}


TABLE 1-Continued

\begin{tabular}{|c|c|c|c|c|c|c|c|c|}
\hline Dilutions of & $0.01 \%$ & $0.02 \%$ & $0.05 \%$ & $0.1 \%$ & $0.2 \%$ & $0.5 \%$ & $1 \%$ & $2 \%$ \\
\hline $\begin{array}{l}\text { Copper pentachlorphenate (Mon- } \\
\text { santo) }\end{array}$ & 27 & 42 & 108 & 111 & \multicolumn{4}{|c|}{ uneaten seven years } \\
\hline \multicolumn{8}{|l|}{$\begin{array}{l}\text { Benzene hexachloride: } \\
\alpha \text { and } \beta \text { (Eastman) }\end{array}$} & 44 End \\
\hline$\gamma$ (duPont) & 136 & 141 & 147 & 189 & 249 & 259 & 303 & End \\
\hline $\begin{array}{l}\text { ordinary DDT (Bureau } \\
\text { of Entomology) }\end{array}$ & & & 25 & 27 & 29 & 35 & 37 & $\begin{array}{l}\text { uneaten } \\
7 \text { years }\end{array}$ \\
\hline Butyl DDT & & & 49 & 51 & 79 & 114 & 119 & 120 End \\
\hline Fluorine DDT (Whitema & & & 7 & 50 & 58 & 151 & 157 & 161 End \\
\hline $\begin{array}{l}\text { Methyl DDT (duPont's } \\
\text { Methoxychlor) }\end{array}$ & & & \multicolumn{6}{|c|}{ uneaten over a year } \\
\hline $\begin{array}{l}\text { Dimethyl-tetrachlorphthalate } \\
\text { (Whitemarsh) }\end{array}$ & & & \multicolumn{6}{|c|}{ uneaten a year and a half } \\
\hline $\begin{array}{l}\text { 1,1-di (2-hydroxy-3,5-dichlor- } \\
\text { phenyl) } 2,2,2 \text {-trichlorethane } \\
\text { (Laurel Hill) }\end{array}$ & & & \multicolumn{6}{|c|}{ uneaten two years } \\
\hline $\begin{array}{l}\text { 1,1-di (2-hydroxy-2,5-dichlor- } \\
\text { phenyl) } 2,2,2 \text {-trichlorethane } \\
\text { (Laurel Hill) }\end{array}$ & & & 36 & \multicolumn{5}{|c|}{ uneaten one year } \\
\hline $\begin{array}{l}\text { 1,1-di (4-hydroxy-3,5-dichlor- } \\
\text { phenyl) } 2,2,2 \text {-trichlorethane } \\
\text { (Laurel Hill) }\end{array}$ & & & 147 & 192 & 330 & 454 & 514 & End \\
\hline $\begin{array}{l}\text { Dilan (Commercial Solvents): } \\
\text { nitro-1,1-bis (p-chloropheny }\end{array}$ & & & & & & & & \\
\hline $\begin{array}{l}\text { propane } \\
\text { butane }\end{array}$ & & & $\begin{array}{l}74 \\
84\end{array}$ & $\begin{array}{r}8.3 \\
335\end{array}$ & $\begin{array}{l}240 \\
\text { unea }\end{array}$ & & $\begin{array}{l}\text { aten } \\
\text { one y }\end{array}$ & $\begin{array}{l}\text { one year } \\
\text { ear }\end{array}$ \\
\hline ramite (Naugatuck) & & & 27 & 80 & 241 & & aten & one yea \\
\hline & & & 20 & 22 & 25 & & 373 & $378 \mathrm{Er}$ \\
\hline 7) & & & 237 & 377 & 473 & unes & aten $\mathrm{t}$ & two year \\
\hline Aldr & & & 363 & 415 & 572 & unea & $\operatorname{aten} t$ & two years \\
\hline Toxaphene (Her & & & 150 & 296 & 298 & 300 & 484 & End \\
\hline Piperonyl Butoxide & & & 19 & 23 & 31 & 181 & 229 & 289 End \\
\hline $\begin{array}{c}\text { Cyclohexanone } \\
\text { (U. S. Industrial Chemicals) }\end{array}$ & & & 17 & 23 & 157 & 219 & uneat & $\begin{array}{l}\text { ten thr } \\
\text { years }\end{array}$ \\
\hline
\end{tabular}

On the basis of results to date, certain recommendations may be made. Of the organic compounds, methyl DDT is clearly superior to ordinary DDT, and being commercially available, should displace it for wood treatment. As the tests were made with solutions in benzol, it is not to be expected that suspensions or other preparations in water will be as deeply penetrating or as effective as solutions. Benzol was also used as a solvent for 1,1-di(2-hydroxy-3,5-dichlorphenyl) 2,2,2-trichlorethane. The solution of dimethyl-tetrachlor-phthalate in acetone could not be diluted with water 
without precipitation, and the acetone solution of ryanodine became milky when dilution with water was attempted. Herein lies the great advantage of copper pentachlorphenate, for although it can not be dissolved satisfactorily in commercial denatured alcohol, under tropical conditions its solution in pure methyl alcohol, acetone or butyl cellosolve has been diluted indefinitely with water without any indication of precipitation. It would appear to be as effective against powder-post beetles as against termites, for after spraying with a $0.2 \%$ solution of copper pentachlorphenate, no more powder fell from a basket from which beetles had already begun to emerge.

Of all the inorganic compounds, the water soluble or the water-miscible solution of copper ammonium fluoride (Wolcott 1949) is unquestionably superior in effectiveness. Recent preparations in both liquid and powder form from the Whitemarsh Laboratories do not require the addition of ammonium hydroxide to the water of dilution to prevent the formation of the blue-grey cloudy precipitate. A one pint bottle of the concentrate dilutes to make one hundred gallons of solution which should protect indefinitely against dry-wood termite attack any wood submerged in it.

With such a variety of effective chemicals for protecting wood, it is now possible to pick and choose, selecting on the basis of cost, or of suitability for the specific use to be made of the impregnated wood. Visual proof of the application of copper ammonium fluoride is afforded by the subsequent blue-grey appearance of light-colored woods, and naturally this chemical should not be used where such a change in the appearance of the wood is undesirable. The dinitro compounds stain the wood a bright yellow, a stain which is also imparted to other objects in contact with the treated wood, but also an unmistakable proof of impregnation. Most of the other effective chemicals give no such visual indication, which is another way of saying that they do not stain the wood, but the proof of their presence lies in the years of service to be expected from such treated woods, free from the danger of early destruction by dry-wood termites.

\section{LITERATURE CITED}

Erdtanan. Holger. 1949. Heartwood Extractives of Conifers: their Fungicidal and Insect-Repellent Properties and Taxonomic Interest. TAPPI, 39 (7): 305-310. Wolcott, George N. 1943. How to make Wood unpalatable to the West Indian DryWood Termite, Cryptotermes brevis Walker. I, With Inorganic Compounds. Caribbean Forester, 4 (4) : 145-156, fig. 3. July, Río Piedras.

- 1946. Factors in the Natural Resistance of Woods to Termite Attack. Caribbean Forester, 7 (2) : 121-149. April, Río Piedras.

-__ 1947. Termite Repellents: a Summary of Laboratory Tests. Bulletin No. 73, Agr. Expt. Station, Univ. P. R., pp 18, tab. 9, ref. 11. October, Río Piedras. . 1949. The Compounds of Copper most effective in making Wood resistant to the Attack of the West Indian Dry-Wood Termite, Cryptotermes brevis (Walker). Caribbean Forester, 10 (3) : 197-202, ref. 3. July, Río Piedras.

- 1950. Benzene Hexachloride as a Termite Repellent. Jour. Agr. Univ. P. R. 31 (3 - July 1947): 224-5, ref. 1. June, Río Piedras. 